\title{
Transfer Pricing Aspects of Cash Pooling Arrangements in Light of the BEPS Action Plan
}

\author{
The author discusses the concept, underlying \\ commercial rationale and types of cash pooling \\ arrangements, and then analyses and comments \\ on the transfer pricing aspects thereof. The \\ analysis also takes into consideration the \\ Actions under the OECD/G20 BEPS Project \\ related to transfer pricing. The author discusses \\ the impact of other BEPS-related actions \\ (domestic and treaty law changes) on cash \\ pooling arrangements, and ultimately suggests \\ a way forward.
}

\section{Introduction: Cash Pooling}

\subsection{The concept and commercial rationale}

Multinational groups have been utilizing cash pools for several decades. ${ }^{1}$ Under such arrangements, multinationals efficiently manage liquidity (working capital) requirements of the group by using surplus cash available with some cash pool participants (also referred to as "members of the group") - typically subsidiaries, to fund the requirements of other cash pool participants. This enables members of a group to support each other financially before having to obtain external financing, which itself has become an expensive source of funding in light of the recent credit turmoil. In effect, multinationals leverage internal finance sources within the group in order to reduce external financing costs. ${ }^{2}$

Broadly, multinationals enter into cash pools to (i) centralize cash management and decision making power for financial arrangements, (ii) obtain favourable deposit and borrowing interest rates in light of their increased cash position, (iii) achieve cost savings on banking transactions and (iv) acquire cash pool benefits available on the difference between debit and credit interest rates. ${ }^{3}$ Cash

Executive Director - Executive Program in Transfer Pricing \& Masters of Advanced Studies in International Taxation, University of Lausanne, Switzerland. The author can be contacted at vikram.chand@unil.ch. He would like to express his gratitude to Mr Markus Wyss (Partner, KPMG Zurich) and Mr Stefaan DeBaets (Transfer Pricing Advisor OECD) who offered valuable comments on this article.

1. A.J. Bakker, Transfer Pricing and Intra-Group Financing: Low-Hanging Fruit?, 15 Derivs. \& Fin. Instrums. 2 (2013), at 30, Journals IBFD; A Storck, The Financing of Multinational Companies and Taxes: An Overview of the Issues and Suggestions for Solutions and Improvements, 65 Bull. Intl. Taxn. 1 (2011), at 33, Journals IBFD; I. Diakonova, S. Huibregste \& G. Körner, Where Do Financial Services Meet Transfer Pricing?, 2 Derivs. \& Fin. Instrums. 2 (2000), at 61, Journals IBFD; PWC, Clarifying the Rules: Sustainable Transfer Pricing in the Financial Services Sector (PWC Apr 2012), at 138; A. Russo \& O. Moerer, Introduction, in Transfer Pricing and Intra-Group Financing (IBFD 2012), at 40-41, Online Books IBFD. PWC, supra n. 1, at 137

3. PWC, supra n. 1, at 137; D. Ledure et al., Financial Transactions in Today's World. Observations from a Transfer Pricing Perspective, 43 Intertax 2 (2014), at 196-197. pooling can be done on either a physical or notional basis (see below).

\subsection{Types of cash pooling}

\subsubsection{Physical cash pooling}

Physical cash pooling ${ }^{4}$ can be on either a zero balancing method $^{5}$ or a target balancing method. Under the zero balancing approach, cash pool participants transfer their entire cash to a cash pool leader. Similarly, under a target balancing approach the cash pool participants transfer their entire cash that exceeds a certain balance to the cash pool leader. However, if the cash pool participants have a negative balance, the cash pool leader transfers funds to them. ${ }^{6}$ In essence, the arrangement ensures that the credit balances are moved (swept) into, and debit balances are covered (swept) out of a single master account.

The following example illustrates the mechanics of a physical cash pooling arrangement. A Co (Parent Co), a tax resident of State $A$, enters into a zero balancing cash pooling arrangement with its subsidiaries $B$ Co, $C$ Co and $D$ Co resident in State $B$, State $C$ and State $D$, respectively (all states are within the European Union). Under the arrangement, $A$ Co - the cash pool leader - sets up a bank account (master, header or concentration account) with BUS bank in State $A$. Similarly, $B$ Co, $C$ Co and $D$ Co set up current bank accounts (sub-accounts that are linked to the master account) with BUS bank. The arrangement (zero balancing) provides that the bank balances of the cash pool participants are transferred to or from the master account on a regular basis (for instance on a daily, weekly or monthly basis).

The bank balances of $B$ Co and $C$ Co show a positive balance of EUR 100 and EUR 150, respectively, whereas that of $D$ Co shows a negative balance of EUR 200. Further, the debit (on negative balances) 7 and credit (on positive balances) interest rates offered by BUS bank are $15 \%$ and $10 \%$, respectively. On a stand-alone basis, $B$ Co and $C$ Co would earn EUR 10 and EUR 15 (combined interest income of EUR 25), while D Co would have an interest expense of EUR 30, thereby leading to a net interest expense of EUR 5 for the entire group.

4. Such arrangements are attractive in jurisdictions that do not apply domestic withholding taxes on outbound interest payments. Even if withholding taxes are applied domestically, such arrangements are popular in jurisdictions that levy nil withholding tax under an applicable tax treaty or the Interest and Royalties Directive (within the European Union)

5. Also known as the cash concentration or sweeping method.

6. S. Tredicine, Tax Treatment of International Cash Pooling Arrangements, 4 Derivs. \& Fin. Instrums. 4 (2002), at 151, Journals IBFD; S. Damji, I. Diakonova \& U. Brügger, Transfer Pricing DNA as a Tool to Achieve the Optimal Balance of Risks and Efficiency, Der Schweizer Treuhänder 3 (2006), at 189. Also known as overdraft interest rates. 
However, by entering into a cash pooling arrangement and concentrating the funds in the master account owned (legally) by $A$ Co, the entire group is in a surplus of EUR 50 (EUR 250 - EUR 200) on which $A$ Co can earn interest income $e^{8}$ of EUR 5 from BUS bank (even though $A$ Co is entitled to receive the income from a legal perspective, the considerations outlined in section 2 . need to be taken into account to determine whether $A$ Co is entitled to receive the interest income from a transfer pricing perspective). To attain this advantage, $B$ Co and $C$ Co have deposited cash in the master account (provided a loan), while D Co has withdrawn cash from the master account (received a loan). ${ }^{9}$ The pooling benefit is depicted in Table 1 .

\begin{tabular}{|l|c|c|c|c|l|l|}
\hline Table 1 & \multicolumn{7}{l|}{$\begin{array}{l}\text { Stand-alone transaction } \\
\text { (without pooling) }\end{array}$} & $\begin{array}{l}\text { Cash } \\
\text { pooling }\end{array}$ & $\begin{array}{l}\text { Pooling } \\
\text { benefit }\end{array}$ \\
\hline & B Co & C Co & D Co & \multicolumn{2}{|c|}{ Total } & \\
\hline Balance & 100 & 150 & $(200)$ & 50 & 50 & \\
\hline $\begin{array}{l}\text { Interest } \\
\text { rate (\%) }\end{array}$ & 10 & 10 & 15 & - & 10 & \\
\hline Interest & 10 & 15 & $(30)$ & $(5)$ & 5 & 10 \\
\hline
\end{tabular}

Typically, at one end of the spectrum, in physical cash pools, the cash pool leader (or the treasury entity of the group) may act as a financial services entity with an external bank structure. ${ }^{10}$ Under such structures, the cash pool leader would enter into a cash management services agreement (for administrative convenience) with a bank pursuant to which the bank accounts of the cash pool participants are netted out for the purposes of determining the balance on which the deposit or overdraft interest rate is applied. Based on these balances, the external bank will have to pay or receive from the cash pool. ${ }^{11}$ Broadly, the cash pool leader engages in borrowing and lending of funds, but operates with a limited amount of equity at risk in relation to the functions performed and risks assumed. For instance the cash pool leader may not have the necessary funds to bear the credit risk (risk associated with a cash pool member defaulting on its borrowing) in the event of its realization.

At the other end of the spectrum, the cash pool leader may act as an entrepreneurial entity (in-house bank structure) $)^{12}$ wherein it carries out functions, assumes risks and employs assets as an external bank. In essence, the cash pool leader acts as counterparty to the transactions and bears risks. ${ }^{13}$ In such situations, in terms of functions, the cash pool leader plans the financial needs of the multinational group, develops the cash pooling concept, and implements the cash pooling concept by (i) negotiating the cash pooling

8. The excess cash may also be invested in short-term limited risk securities. PWC, supra n. 1, at 138.

9. These loans are mostly regarded as short-term loans. PWC, supra n. 1, at 138.

10. A financial services entity is an entity that is responsible for the receipt and payment of interest within a group of companies. Russo \& Moerer, supra n. 1, at 15.

11. J. Hollas \& G. Hands, Transfer Pricing and Intra-group Cash Pooling (17 Sept. 2013), available at http://www.tpa-global.com/news/2013/09/17/ transfer-pricing-and-intra-group-cash-pooling. See also the ConocoPhillips case in section 2.3.3.1.

12. Hollas \& Hands, supra n. 11.

13. Bakker, supra n. 1, at 30. arrangement and interest rates, (ii) drafting intercompany loan agreements, (iii) coordinating the cash pool and (iv) managing internal offsets of debit and credit positions. In terms of risks, in addition to bearing the credit risk, the cash pool leader also bears the interest rate risk (risk associated with changes in the market interest rates) and foreign exchange risk (risk that exists when the financial transactions between the cash pool members are denominated in a currency other than that of the base currency of the cash pool leader). ${ }^{14}$

The difference between an external bank structure and an in-house bank structure is that under the former, the cash pool participants have intercompany accounts with an external bank, whereas under the latter, the cash pool participants have intercompany accounts with the in-house bank (treasury entity). This would imply that under an in-house bank structure, as the depositor cash pool participants have made deposits with the treasury entity (not with an external bank), they assume a significantly higher credit risk with respect to these deposits. ${ }^{15}$ From a transfer pricing perspective, it is crucial that the transactions be appropriately delineated and a proper comparability analysis including a functional analysis be undertaken to determine the actual roles and responsibilities of the participants, as such arrangements may fit into one of these categories or maybe somewhere between the two spectrums.

\subsubsection{Notional cash pooling}

Under a notional ${ }^{16}$ cash pooling arrangement, ${ }^{17}$ cash is not physically transferred to any bank account. This type of arrangement does not lead to any intra-group loans. ${ }^{18}$ Under the arrangement, the cash pool participants operate accounts directly with the bank. The bank calculates the debit and credit interest rates on each participant's individual bank account and then subsequently calculates the combined notional balance of all bank accounts (for instance on a daily, weekly or monthly basis).$^{19}$ Thereafter, the cash pool benefit is determined based on the notional balance. The cash pool benefit is paid directly to the cash pool leader (master account in the name of the cash pool leader). ${ }^{20}$ Typically, in notional cash pools, the cash pool leader does not act as counterparty to the transactions and does not bear risks. ${ }^{21}$ In such situations, the cash pool leader only coordinates the cash pool and manages inter-

14. In these situations, the cash pool leader could be entitled to a spread on the interest rates. See section 2.5 .

15. Hollas \& Hands, supra n. 11.

16. Also known as interest compensation cash pool.

17. Such arrangements are attractive in (i) jurisdictions that apply withholding taxes that cannot be completely eliminated by tax treaties and (ii) jurisdictions that have legal restrictions (typically developing countries such as Brazil, China or India) which restrict the physical transfer of funds. Storck, supra n. 1, at 33-34. However, several countries (e.g. the United States and Germany) do not allow notional cash pooling. S. Hillman, Notional vs. Physical Cash Pooling Revisited, International Treasurer (2011), at 1 available at http://www.treasuryalliance.com/assets/publications/cash/ Treasury_Alliance_Notional_Physical_Pooling_Revisited.pdf.

18. Bakker, supra n. 1, at 30; Diakonova, supra n. 1, at 61.

19. PWC, supra n. 1, at 138 .

20. As an alternative, the bank could pay the benefit directly to the participants by amending the interest rates. Tredicine, supra n. 6, at 152.

21. Bakker, supra n. 1, at 31 
nal offsets of debit and credit positions. Essentially, it acts as a service provider. Moreover, in such cash pools, the cash pool participants may have to provide cross-guarantees to the bank to prevent the bank from bearing the risk associated with a cash pool participant's defaulting.

\section{Transfer Pricing Aspects of Cash Pooling Arrangements}

\subsection{Intra-group transactions}

Article 9(1) of both the OECD ${ }^{22}$ and $\mathrm{UN}^{23}$ Model Conventions provides that transactions between associated enterprises must be at arm's length. This means that, from a transfer pricing perspective, intercompany loans provided in physical cash pooling arrangements must be at arm's length (the funding itself and interest rates). This issue is not relevant for notional cash pooling arrangements, as there is no real movement of funds. Further, if one assumes that the cash pool is in an overall negative balance, the bank would grant a loan to the cash pool leader (under physical arrangements) or to the cash pool participant directly (under notional arrangements) pursuant to a credit facility on which interest must be paid. ${ }^{24}$ More often than not, a member of the cash pool must provide a bank with a guarantee on behalf of another participant to cover the default risk associated with this loan. Such guarantees also must be at arm's length. ${ }^{25}$ Furthermore, under both types of arrangements, the remuneration that the cash pool leader obtains must be at arm's length. Moreover, a determination of an arm's length allocation of the cash pool benefit among the cash pool participants needs to be undertaken in either type of cash pool.

In 2013, the OECD initiated its work on BEPS (the BEPS Project) ${ }^{26}$ It was contended that the current transfer pricing system had led to serious BEPS-related concerns. Nevertheless, replacing the arm's length principle was not viable, and a better solution is to ensure that transfer pricing outcomes are in line with "value creation.". ${ }^{27}$ In this regard, the current OECD Transfer Pricing Guidelines (2010), ${ }^{28}$ which propagate the use of the arm's length principle, have significantly been revised in light of Actions 8-10 29 and Action

22. OECD Model Tax Convention on Income and on Capital art. 9(1) (26 July 2014), Models IBFD.

23. United Nations Model Double Taxation Convention between Developed and Developing Countries art. 9(1) (2011), Models IBFD.

24. PWC, supra n. 1 , at 138

25. Id.

26. OECD, Action Plan on Base Erosion and Profit Shifting (OECD Publishing 2013), International Organizations' Documentation IBFD.

27. V. Chand \& S. Wagh, The Profit Split Method: Status Quo and Outlook in Light of the BEPS Action Plan, 21 Intl. Transfer Pricing J. 6 (2014), at 405, Journals IBFD.

28. OECD, Transfer Pricing Guidelines for Multinational Enterprises and Tax Administrations (OECD 2010), International Organizations' Documentation IBFD.

29. These Actions have led to changes in Chapter I (guidance for applying the arm's length principle), Chapter II (transfer pricing methods), Chapter VI (intangibles), Chapter VII (intra-group services) and Chapter VIII (cost contribution agreements). OECD, Aligning Transfer Pricing Outcomes with Value Creation - Actions 8-10 Final Reports, OECD/G20 Base Erosion and Profit Shifting Project (OECD Publishing 5 Oct. 2015), International Organizations' Documentation IBFD.
$13^{30}$ of the BEPS Action Plan. This will lead to the publication of revised OECD Guidelines in the near future. The following analysis takes into consideration both the current and revised OECD guidance.

\subsection{Recognition of arrangements}

Only members of a multinational group enter into cash pooling arrangements in order to benefit from group synergies. ${ }^{31}$ Such arrangements are rarely found between independent parties. As a starting point, the question arises as to whether the arm's length principle should be applied to such arrangements even though independent enterprises typically do not enter into such arrangements. The OECD Guidelines highlight that practical difficulties arise when applying the arm's length principle to such situations. This is because "little or no direct evidence of what conditions would have been established by independent enterprises" exists. ${ }^{32}$ Nevertheless, the OECD Guidelines provide that the fact that independent enterprises do not enter into such transactions does not necessarily imply that the controlled transactions are not at arm's length. Thus, the arm's length nature of cash pooling arrangements must be ascertained (see sections 2.3.-2.6.).

A related question arises as to the circumstances under which such arrangements may be disregarded. In principle, if the controlled transactions are accurately delineated, ${ }^{33}$ with the effect that the economic substance of the cash pooling arrangement (such as functions, assets and risks assumed by the members to the arrangement, taking into account the economic circumstances and business strategies) $^{34}$ is aligned with the legal arrangements ${ }^{35}$ (contractual terms), tax authorities should not disregard the transaction. ${ }^{36}$ However, even if the form and economic substance coincide, the OECD Guidelines provide that the transactions may be recharacterized if the arrangement, viewed holistically, differs "from those which would have been adopted by independent enterprises behaving in a

30. This Action has led to changes in Chapter V (transfer pricing documentation). OECD, Transfer Pricing Documentation and Country-by-Country Reporting - Action 13: 2015 Final Report, OECD/G20 Base Erosion and Profit Shifting Project (OECD Publishing 5 Oct. 2015), International Organizations' Documentation IBFD.

31. H.M. Andresen, ConocoPhillips Case: Implications in Norway and Beyond, 17 Intl. Transfer Pricing J. 6 (2010), at 464, Journals IBFD. See also S. Assef \& D. Boer, Safe Dive into a Cash Pool, Treasury \& Risk (1 Oct. 2013), available at http://www.treasuryandrisk.com/2013/10/01/safe-dive-intoa-cash-pool? $\mathrm{t}=$ treasury-management\&page $=3$.

32. OECD Guidelines, para. 1.11.

33. The application of the arm's length principle requires a comparison of the related-party transactions with comparable uncontrolled transactions. Two aspects of this analysis are to (i) identify the contractual terms between related parties and the economically relevant aspects attached to such terms in order to properly delineate the related-party transactions and (ii) undertake a comparability analysis to compare the controlled transactions with uncontrolled transactions. OECD, Actions 8-10 Final Reports, supra n. 29, para. 1.33. However, if the form does not correspond to the economic substance, the economic substance should be used to delineate the transactions. OECD, Actions 8-10 Final Reports, supra n. 29, paras. $1.42-1.50$.

34. The economically relevant characteristics must be documented in the local file. OECD, Action 13 Final Report, supra n. 30, para. 22.

35. However, if the form does not correspond to the economic substance, the economic substance should be used to delineate the transactions. OECD, Actions 8-10 Final Reports, supra n. 29, paras. 1.42-1.50.

36. OECD Guidelines, para. 1.65 
commercially rational manner." ${ }^{37}$ In the author's opinion, if the commercial rationale of entering into a cash pooling arrangements is demonstrated (such as savings on banking costs, the possibility to obtain favourable credit and debit interest rates and centralization of treasury functions), tax authorities should not disregard such arrangements.

\subsection{Intra-group loans}

\subsubsection{The arm's length analysis}

The movement of funds among the cash pool leader and cash pool participants in physical cash pooling arrangements creates intercompany loans (mostly short-term loans although long-term positions are also feasible)..$^{38}$ Two questions ${ }^{39}$ need to be answered, namely (i) whether the intercompany loans ${ }^{40}$ (deposits and drawdowns) are at arm's length and (ii) whether the interest rates on such loans are arm's length.

Generally, a transfer pricing analysis of intercompany loans involves a two-step process. First, the characteristics of the borrowing entity must be established. This analysis should address the following questions: ${ }^{41}$ (i) could the borrowing entity obtain a similar level of debt from a thirdparty lender ${ }^{42}$ and (ii) would the borrowing entity actually borrow a similar amount at arm's length, given the performance of its business. ${ }^{43}$ Essentially, this step entails a credit rating evaluation ${ }^{44}$ of the borrower on a standalone basis (adjustment to the credit rating of the borrower will be required to be made, taking into consideration the implicit support that it receives from being associated with the entire group; see section 2.4.).

Second, an arm's length interest rate ${ }^{45}$ needs to be established in light of a credit rating evaluation. ${ }^{46}$ In practical terms, the screening process applied by commercially

37. OECD Guidelines, para. 1.65; OECD, Actions 8-10 Final Reports, supra n. 29, paras. 1.122-1.125.

38. Bakker, supra n. 1, at 32. However, such long-term positions could possibly be recharacterized as long-term loans.

39. Damji, Diakonova \& Brügger, supra n. 6, at 189.

40. It is assumed that the loans qualify as debt under the relevant domestic tax rules. PWC, supra n. 1, at 131 .

41. Russo \& Moerer, supra n. 1, at 15; Damji, Diakonova \& Brügger, supra n. 6 , at 189 .

42. The could analysis focuses on what a lender would be prepared to lend to the borrower, taking into consideration, for example, the latter's capacity to borrow, risk of default, assets that can be provided as security, liabilities that can have a negative effect on the intercompany loans and the industry in which the borrower operates. Her Majesty's Revenue \& Customs (HMRC), Transfer Pricing: Thin Capitalisation Legislation and Principles: The "Would" and "Could" Arguments, INTM 413030.

43. The would analysis focuses on how much, and under what conditions, a borrower would have borrowed at arm's length, taking into consideration (i) whether the borrower would have taken a loan at arm's length given its financial situation, (ii) the amount of debt and whether taking that amount leaves room to absorb cyclical or seasonal variations, unforeseen events or a fluctuation in interest rates or profits, (iii) its the costs of borrowing and (iv) its debt servicing ability and the possibility to have sufficient cash to operate as a profitable organisation. HMRC, supra n. 42.

44. This evaluation estimates the ability of the borrowing entity to repay its debt.

45. Interest (fixed or floating) consists of a base rate (risk-free rate) that is determined on the basis of currency and maturity and a credit spread that is determined on the basis of the risks undertaken by the lender with respect to the lending transaction.

46. Damji, Diakonova \& Brügger, supra n. 6, at 189; Russo \& Moerer, supra n. 1 , at 15 . independent banks to determine the creditworthiness of the borrower needs to be undertaken. The credit rating ${ }^{47}$ obtained pursuant to the multi-pronged creditworthiness analysis ${ }^{48}$ lays the foundation to determine under what conditions a loan can be issued in related-party settings. Furthermore, the factors influencing the interest rate determination ${ }^{49}$ (terms and conditions of the loan), such as the currency, tenure of the loan, seniority or subordination, type (fixed or floating), loan repayment schedule, pre-payment options, convertibility (into equity) and security, need to be analysed to determine the arm's length interest rate..$^{50}$ The most common transfer pricing method applied to benchmark interest rates is the comparable uncontrolled price (CUP) method,,$^{51}$ using internal ${ }^{52}$ or external CUPs ${ }^{53}$ as may be available. ${ }^{54}$

\subsubsection{Application to cash pooling arrangements}

With respect to cash pooling arrangements, in determining the arm's length credit or debit interest rates on the intercompany deposits and loans, respectively, it is essential that the creditworthiness of the borrower participants (cash pool leader or cash pool participants depending on the structure), on a stand-alone basis, be ascertained (adjusted for implicit support). ${ }^{55}$ The analysis lays down the basis for determining the arm' s length spread ${ }^{56}$ that can be added to the base interest rate (e.g. LIBID, ${ }^{57} \mathrm{LIBOR}^{58}$ or other bank rates). Thereafter - based on the credit ratings, the contractual terms (the loan terms and conditions) and actual conduct of the parties - CUPs (internal or external $)^{59}$ need to be found to benchmark the con-

47. References can be made to Moody's, Fitch and Standard and Poor's rating agencies. Russo \& Moerer, supra n. 1, at 19-29.

48. The analysis includes an analysis of the business/industry in which the borrower operates, an operational risk assessment of the borrower, financial statement analysis, cash flow analysis, forecast and probability measurement analysis, credit scoring analysis and comparable analysis. For a detailed description of these parameters, see Russo \& Moerer, supra n. 1, at 16-30.

49. The US transfer pricing regulations also provide that the credit rating of the borrower should be ascertained with respect to determining interest rates. US: Treas. Reg. sec. 1.482-1(d)(4)(ii)(D) (1994).

50. Damji, Diakonova \& Brügger, supra n. 6, at 188; Bakker, supra n. 1, at 28-29.

51. Russo \& Moerer, supra n. 1, at 29. In some cases, tax authorities have also accepted the build-up approach. Essentially, this approach estimates a risk-free rate to which a credit risk and term risk premium is added, based on spreads available at corporate bonds. In other cases, tax authorities have also accepted bank quotes to determine if the interest rate received (paid by the borrower) is at arm's length.

52. Internal CUPs may exist. More often than not, adjustments will be required to improve comparability. Bakker, supra n. 1, at 29.

53. External CUPs may exist where it is possible to find comparable loans between unrelated parties in the public domain. Bakker, supra n. 1, at 29.

54. In situations where comparables do not exist, the result obtained through the application of the fair market yield curves (e.g. the Bloomberg yield curves) have been accepted. Bakker, supra n. 1, at 29.

55. PWC, supra n. 1, at 140-141

56. The OECD Guidelines provide that "in respect of financial services such as loans ... remuneration would generally be built into the spread and it would not be appropriate to expect a further service fee to be charged". OECD Guidelines, para. 7.15.

57. The London Interbank Bid Rate. See http://www.investopedia.com/ terms/l/libid.asp.

58. The London Interbank Offer Rate. See http://www.investopedia.com/ terms/l/libor.asp.

59. The external CUP analysis, which is based on information obtained in the public domain (databases such as Loan Connector), results in interquartile ranges of base interest rates and credit spreads that can be used as arm's 
trolled interest rate. If CUPs are unavailable, the taxpayer could explore options realistically available to it to justify the arm's length nature of its dealing, ${ }^{60}$ taking into consideration the contributions of all cash pool members. For instance, net depositors could demonstrate the arm's length nature of interest rates by benchmarking them with the option of depositing the funds with an external bank, although such an alternate option was rejected in the court cases discussed below. Those cases dealt with the arm's length determination of interest rates in cash pooling arrangements.

\subsubsection{Court decisions on interest payments}

\subsubsection{The ConocoPhillips case ${ }^{61}$}

ConocoPhillips Inc, a US-headquartered company, owned subsidiaries worldwide. It also owned two subsidiaries in Norway, namely COPSAS and NCOPAS. ConocoPhillips Inc, along with its subsidiaries (as cash pool participants), entered into a multi-currency physical cash pooling arrangement with Bank of America (bank). The group's treasury centre, ConocoPhillips UK, managed the arrangement. Pursuant to the arrangement, the cash pool participants were required to place their surplus cash with the bank (sub-accounts). Interest was debited or credited based on the group's top account balance (sub-accounts aggregated into the master account). A positive balance on the top account entitled the arrangement to earn an interest rate of LIBID minus 25 basis points (interest from the bank), whereas a negative balance attracted an interest rate of LIBOR plus 25 basis points (payment to the bank). Generally, a spread of 62.5 basis points was available, as the LIBOR rate was 12.5 basis points higher than the LIBID rate. However, deposits and withdrawals by the cash pool participants to/from the cash pool respectively attracted the same interest rates of LIBID minus 25 basis points (interest rate on net deposits).

In this case, the top account always reflected a positive balance. Furthermore, ConocoPhillips Inc guaranteed the accounts even though all the entities in the group were jointly and severally liable for the arrangement. COPSAS and NCOPAS were net depositors to the arrangement and were entitled to a deposit interest rate of LIBID minus 25 basis points. The key question that arose in this case, from a Norwegian tax and transfer pricing perspective, was whether the deposit interest rate received by the taxpayers, namely COPSAS and NCOPAS, was at arm's length.

The taxpayers argued that independent parties do not enter into cash pooling arrangements. Therefore, it was not possible to compare controlled transactions with uncontrolled transactions. Consequently, it was necessary to compare the closest option that exists between independent parties. The closest option that was available to the taxpayers was to deposit the funds with an independent bank. ${ }^{62}$ Nevertheless, as the interest rates that the taxpayers received from the arrangement was higher than the rate that they could have achieved by depositing the funds with an independent bank, it was contended that the transactions were at arm's length. It was also contended that the cash pooling benefit should not be divided among the cash pool members. As the cash pool benefit was created by the treasury entity, it should reside with that entity. ${ }^{63}$

The tax authorities argued that the cash pooling arrangement should be seen in a holistic manner, and that the cash pooling benefit should be split among the participants in light of their respective contributions (bargaining power). The alternate option available to the taxpayers (i.e. depositing the funds with a bank) ignored the actual cash pooling arrangement and the bargaining power position of the parties. It was also contended that deposits and withdrawals by the cash pool participants to/from the cash pool respectively attracted the same interest rates of LIBID minus 25 basis points. Accordingly, net depositors were in a similar situation to net debtors, even though the former's bargaining power (on account of their cash balances) was higher than that of the latter. Thus, net debtors were enjoying the cash pool benefit (as opposed to the net depositors) due to similar interest rates.

The Bogarting Court of Appeal decided in favour of the tax authorities. The Court held that the pooling benefit should be split among all the participants in light of their respective contributions. Net depositors to the arrangement were, indeed, in a better bargaining position, as they were the ones that were creating profit opportunities for the group. Accordingly, if they had entered into similar arrangements with independent parties, they would have obtained a higher interest rate in light of their bargaining position. Therefore, the taxpayers did not receive an appropriate compensation that reflected their contributions. Accordingly, the taxable income of the taxpayers was increased.

An interesting question arises within the context of the case, namely whether the deposit and lending rates offered by the bank can be used as CUPs for the rates charged by the cash pool leader to the cash pool participants (depositors and lenders). In the author's opinion, a mechanical transposition of the rates charged by the bank to the rates charged by the cash pool leader to its members does not reflect an arm's length rate. If the bank charges the cash pool leader a debit interest rate of LIBOR plus 25 basis points on negative balances in the master account, that rate should not be mechanically applied by the cash pool leader to funds provided to a participant. Similarly, if the bank provides the cash pool leader with a credit interest rate of LIBID minus 25 basis points on positive balances in length credit and debit interest rates within the cash pool arrangement. PWC, supra n. 1, at 141. See also the Bombardier case discussed in section 2.3.3.2.

60. OECD Guidelines, paras. 1.34 \& 9.59-9.64. See also S. Parekh, The Concept of "Options Realistically Available" under the OECD Transfer Pricing Guide lines, 22 Intl. Transfer Pricing J. 5 (2015), at 297-307, Journals IBFD.

61. Andresen, supra n. 31, at 461-463. See also Bakker, supra n. 1, at 31-32.
62. The author understands that the taxpayers presented external CUP evidence on deposit interest rates that could have been achieved from independent banks.

63. The author could not manage to obtain a detailed functional analysis of the cash pooling arrangement. Accordingly, it is difficult to ascertain whether the treasury entity should have been compensated as an entrepreneur or a service provider. See section 2.5 . 
the master account, that rate should not be mechanically applied by the cash pool leader to funds deposited by a participant. This is because a direct application of the rates does not take into account the functional and risk analysis of the parties to the arrangement. A credit rating analysis of all the pool members is essential to justify the arm's length lending and borrowing rates. Accordingly, different deposit and lending rates could apply to the pool participants. ${ }^{64}$

\subsubsection{The Bombardier case $^{65}$}

The Canadian Bombardier Group owned subsidiaries worldwide. It also owned a subsidiary in Denmark (the taxpayer). The taxpayer entered into a zero-balancing cash pooling arrangement with a related Swiss entity that was appointed as the cash pool administrator. Pursuant to the arrangement, the taxpayer was required to deposit its surplus funds in the cash pool. Furthermore, the taxpayer could also borrow the deposited funds and withdraw additional funds, if required. The Swiss entity was responsible for establishing cash pool accounts, coordinating the cash pool, providing documentation and determining interest rates. Furthermore, the Swiss entity also took care of other treasury-related activities. ${ }^{66}$ Under the arrangement, deposits into the pool attracted interest rates of daily overnight bank rates minus 50 basis points, while withdrawals attracted interest rates of daily overnight bank rates plus 115 basis points. According to the taxpayer, the spread on deposits was equal to deposit rates offered by independent banks, and such deposits enabled the Swiss entity to negotiate external party funding at cheaper rates for the Bombardier Group.

During the years under audit, the taxpayer had surplus cash and deposited these amounts under several shortterm agreements (and received interest). However, due to insufficient liquidity management, the taxpayer had a negative balance for a few months and was therefore required to withdraw funds (and pay interest). The key question that arose in this case, from a Danish transfer pricing perspective, was whether the interest rate received/paid by the taxpayers was at arm's length.

The Swiss entity did not have its own independent credit rating. However, the Bombardier Group had a credit rating of $\mathrm{Ba} 2 / \mathrm{BB}$. Moreover, the taxpayer failed to provide any documentation explaining how the rates were calculated. Furthermore, from a risk appetite perspective, the taxpayer bore the debtors risks with respect to the deposits. However, the Swiss entity did not bear any risks with respect to the withdrawals by the taxpayer, as the former already had its deposits.
The tax authorities did not agree with the spread earned by the Swiss entity and equalized the deposit interest rates and withdrawal interest rates. Further, they calculated the interest on the net balance of the deposits. Moreover, due to the lack of documentation, the tax authorities determined the interest rate based on an external CUP analysis, taking into consideration the credit rating of the Bombardier Group. The fact that the interest rate received/paid by the taxpayer was equivalent to the interest rate available from independent parties was not considered relevant, as the latter rates did not take into consideration the credit risk assumed by the taxpayer (a similar argument was made by the tax authorities and upheld by the Court of Appeals in the ConocoPhillips case). Nevertheless, the tax authorities agreed that the Swiss subsidiary should be paid a service fee of $0.25 \%$ for its treasury-related activities.

The taxpayer appealed the decision of the tax authorities before the Danish Administrative Tax Court. The Court upheld most of the findings of the tax authorities. In particular, the Court held that the Swiss entity was not entitled to a spread $(-0.5$ to +1.15$)$. This was because that entity did not bear the credit risk with respect to the arrangements. The author agrees with the findings of the Court. If the cash pool administrator does not bear any credit risks, it should not be entitled to a spread. On the other hand, it should be entitled to a service fee for the administrative activities it undertakes (see section 2.5.).

\subsection{Intra-group guarantees ${ }^{67}$}

\subsubsection{The arm's length analysis}

The question arises as to how do to determine the arm's length charge with respect to guarantees. The OECD Guidelines, ${ }^{68}$ in the context of intra-group services, provide that two questions that must be answered with respect to the provision of a guarantee, namely (i) whether an intra-group service is provided and, if so, (ii) whether the intra-group charge with respect to such service is at arm's length. ${ }^{69}$

The response to the first question depends on whether the guarantee provides the recipient with economic and commercial value to enhance its commercial position. ${ }^{70}$ The commercial position of the guarantee recipient is enhanced when the provision of a guarantee improves the credit rating of the recipient in such a manner that the recipient can obtain a loan at lower interest rates (or interest rates applicable to the guarantor). In this regard, a distinction must be drawn between passive association and active promotion of a multinational group's attributes ${ }^{71}$ (or deliberate concerted action).

64. M. Breggen, Netherlands, in Transfer Pricing and Intra-Group Financing, supra n. 1, at 436-437.

65. E. Vistisen, Bombardier Case: First Published Cash Pool Decision, 21 Intl. Transfer Pricing J. 3 (2014), at 464, Journals IBFD. See also E. Vistisen, Bombardier Cash Pool Decision (21 Jan. 2014), available at http://www. vistisenlaw.com/bombardier-cash-pool-decision.

66. Such as liquidity, interest and risk management, insurance, letters of credit and accounting for European operations.

67. The author focuses on the provision of explicit guarantees within a multinational group, as such instruments create a legally enforceable commitment for the guarantor.

68. OECD Guidelines, para. 7.5

69. For a detailed analysis, see V. Averyanova \& J. Sampat, Transfer Pricing Aspects of Intra-Group Financial Guarantees in Light of the BEPS Action Plan, 22 Intl. Transfer Pricing J. 6 (2015), Journals IBFD.

70. OECD Guidelines, para. 7.6.

71. OECD Guidelines, para. 7.13. 
The following example can be used to illustrate this difference. The credit rating of a parent company in the $X Y Z$ group is AAA. Its subsidiary's stand-alone credit rating is Baa. On an individual basis, the subsidiary can obtain a loan from a bank at $6 \%$. However, due to its affiliation to the group, the subsidiary's credit rating is pushed up to A. ${ }^{72}$ This enables the subsidiary to obtain a loan at $4 \%$ from independent banks. Nevertheless, the parent company decides to provide a guarantee to its subsidiary which then pushes up the credit rating of the subsidiary to AAA. This deliberate concerted group action enables the subsidiary to obtain a loan at $2 \%$ from independent banks. The revised OECD Guidelines ${ }^{73}$ (clearly inspired by the GE Capital case) ${ }^{74}$ provide that if the subsidiary has a higher credit rating, due to its group membership (taking the loan at 4\%), than the credit rating it could achieve on an individual basis (taking the loan at 6\%), no service is provided by the parent to the subsidiary, as the latter company receives only an incidental benefit by being associated with the group. However, the revised OECD Guidelines ${ }^{75}$ also provide that an intra-group service is provided when the provision of the guarantee enhances the credit rating of the subsidiary from A to AAA - which thereby enables it to obtain a loan at $2 \%{ }^{76}$ The author agrees with this approach $^{77}$ although it may be disputable. ${ }^{78}$

Continuing with the previous illustration, with respect to the second question, the arm's length guarantee fees should be determined as the difference between the interest rate that the subsidiary can obtain on a stand-alone basis, as adjusted for implicit support (4\%) and the inter-

72. The example assumes that the multinationals group rating is higher than the stand-alone rating of the subsidiary. However, there could be situations where the stand-alone rating of entities is higher than that of the group.

73. OECD, Actions 8-10 Final Reports, supra n. 29, paras. 1.164-1.166 \& paras. 7.12-7.13.

74. CA: TCC, 4 Dec. 2009, General Electric Capital Canada, Inc. v. Her Majesty The Queen, 2009 TCC 563, aff'd 2010 FCA 344 (1 Nov. 2010). See also Ledure et al., supra n. 3, at 352-353.

75. OECD, Actions 8-10 Final Reports, supra n. 29, para. 1.167.

76. In contrast to the above illustration, assume that an independent bank, after analysing the financial position of the subsidiary, refuses to provide a loan. This is because the bank considers the subsidiary to be financially weak on a stand-alone basis. In such circumstances, if the parent company provides a guarantee subsequent to which the bank provides a loan to the subsidiary, it could be argued that an intra-group service is not provided even though the guarantee enhances the commercial position of the subsidiary. The OECD Guidelines provide that, in order to determine the arm's length price for intra-group services, the matter should be seen from the perspective of both the service provider and service recipient. In all likelihood, an independent enterprise would not provide a guarantee, as it will not be willing to accept the risks associated with the transaction (as the subsidiary is financially weak). Thus, if the parent provides a guarantee, it would do so in its capacity as a shareholder. Accordingly, no remuneration should be charged, as the service amounts to a shareholder activity. Russo \& Moerer, supra n. 1, at 33.

77. See e.g. the position of the Dutch tax authorities in Decree of 14 November 2013, IFZ 2013/184M, International Tax Law. Transfer prices, application of the arm's length principle and the Transfer Pricing Guidelines for Multinational Enterprises and Tax Administrations (OECD Guidelines). For an unofficial translation by KPMG Meijburg \& Co/KPMG Global Transfer Pricing Services, see 21 Intl. Transfer Pricing J. 2 (2014), Journals IBFD (Decree of 14 November 2013, IFZ 2013/184M).

78. See e.g. C. Schultz, National Foreign Trade Council, Comments on OECD Revised Discussion Draft on Transfer Pricing Aspects of Intangibles and White Paper on Transfer Pricing Documentation (30 Sept. 2013), at 4-5, available at http://www.nftc.org/default/Publications/Tax/Comments $\% 20$ OECD\%20on\%20the\%20Intangibles.pdf. est rate that the subsidiary can obtain as a result of the guarantee (2\%). This would mean that the guarantee fee should be calculated within the ranges of $0 \%$ to $2 \%$. If the borrower were to be required to pay the entire saving $(2 \%)$ as the fee, it would not make sense for it to enter into the guarantee arrangement. At the same time, if the guarantee provider did not receive a share of the saving (2\%), it would not make sense for it to enter into the guarantee arrangement. Therefore, the synergistic benefit must be split. In these situations, the revised OECD Guidelines provide that it is necessary to split the benefits of the synergies among the participants in proportion to their respective contributions. $^{79}$

\subsubsection{Application to cash pooling arrangements: The Portuguese Arbitration Tax Court decision ${ }^{80}$}

Cross guarantees ${ }^{81}$ (or upstream ${ }^{82}$ or downstream ${ }^{83}$ guarantees) could be provided in cash pooling arrangements. Accordingly, it becomes imperative to analyse whether a guarantee fee is necessary. Ideally, if a guarantee issued by one entity within the group pushes up the credit rating of another entity over and above implicit support, a guarantee fee may be payable. The following court case arrives at a similar conclusion, although the author understands that there was no discussion regarding implicit support.

A parent company and its Portuguese subsidiary (the taxpayer) entered into a notional cash pooling arrangement with a Dutch bank with which they held bank accounts. Pursuant to the arrangement, the parent and the subsidiary provided cross-guarantees to each other for their respective account balances. In effect, this meant that each cash pool participant in the notional pool agreed to guarantee the liabilities (debit balances) of the other cash pool participants to the bank. In this case, the taxpayer had a good financial standing and had higher credit balances in comparison to its parent (which was in a deficit position). Further, even though the cash pool participants crossguaranteed each other, the risk of compensating the bank for debit balances of other cash pool participants never materialized during the year under audit. Moreover, in addition to virtually merging balances, certain clauses of the agreement restricted the subsidiary from obtaining loans from the Dutch bank, whereas no such restriction was placed on the parent entity. In other words, the parent had access only to the master account.

79. OECD, Actions 8-10 Final Reports, supran. 29, para. 1.162. In practice, the CUP method (credit default swaps, letter of credit fees, commitment fees), the cost benefit analysis approach, the contingent put option approach and the cost of capital method are used to price a guarantee fee payment. Bakker, supra n. 1, at 33; Russo \& Moerer, supra n. 1, at 34.

80. F. Sousa \& B. Santiago, Portuguese Arbitration Tax Court Rules on Notional Cash Pooling Arrangements, Tax Notes Intl. (3 June 2013), at 999-1003. See also C. Scholz et al., Comparison of the Tax Treatment of Inter Company Cash Pools in Europe, Transfer Pricing Intl. J. (BNA) (Apr. 2015). A proper analysis of this case could not be made due to non-availability of detailed facts.

81. Typically, issued by group companies whereby all the group members are jointly and severally liable to the creditors (banks). PWC, supra n. 1, at 146.

82. Typically, issued by subsidiaries to creditors (banks) for the benefit of the parent company. PWC, supra n. 1, at 146.

83. Typically, issued by parent companies to creditors (banks) for the benefit of the subsidiary. PWC, supra n. 1, at 146. 
The tax authorities argued that the taxpayer had provided a guarantee to the Dutch bank on behalf of the parent company in light of its strong financial position. This guarantee led the parent to obtain a higher credit rating, which in turn helped the parent to obtain better interest rates from the Dutch bank (on future loans). Further, as certain clauses of the agreement restricted the taxpayer from obtaining loans, in essence, the taxpayer had provided a guarantee to the parent. Accordingly, the parent should pay a guarantee fee to the subsidiary.

After reviewing the terms and conditions of the agreement in detail, the Portuguese Arbitration Tax Court held that, even though the arrangement was called a cash pooling arrangement, a proper analysis of the facts and circumstances (also the agreement clauses) of the taxpayer led the Court to believe that the arrangement was a contract of mixed nature which resulted in the subsidiary's providing a guarantee to the parent. The key takeaway from this case is that if the terms and conditions of the cash pooling arrangement differ from normal circumstances, courts could recharacterize such arrangements in light of their economic substance. This recharacterization mechanism is also supported by the OECD Guidelines (see section 2.2.). Accordingly, the contractual terms must be carefully reviewed prior to being executed.

Further, in notional arrangements which provide for cross-guarantees, it could be argued that an intra-group service is not provided, as independent enterprises do not enter into joint liability arrangements. In fact, the Dutch tax authorities consider that an explicit charge is not required, as cross-guarantees are put in place due to shareholder relations. Moreover, it is asserted that an intragroup service is not rendered, as the joint liability of the cash pool participants - coupled with fluctuating cash pool balances - should offset benefits that could trigger a guarantee claim. ${ }^{84}$

In the author's opinion, a credit rating analysis of all the participants in a notional cash pool must be undertaken. Based on this analysis, the impact of cross-guarantees needs to be analysed. If it is established that the availability of the cross-guarantee pushes up the credit rating of the loan recipient (over and above implicit support), a fee should be payable. However, such fees should not be payable when the "fees are already priced in interest rates, for instance, if the external bank offers implicit guarantee providers with more favourable interest rates and implicit guarantee receivers less favourable interest rates in the context of the cash pool" 85

\subsection{Arm's length remuneration for the cash pool leader}

The arm's length remuneration for the cash pool leader depends on the functions it performs, risks it assumes and assets it employs. In physical cash pooling arrangements, the cash pool leader may act as an internal bank. In such cases, due to its entrepreneurial activities, the cash pool

84. Scholz et al., supra n. 80 , section IV B.

85. Scholz et al., supra n. 80, section V B. leader's remuneration should ideally consist of the difference between the debit and credit interest rates. ${ }^{86}$ The interest rate spread is directly proportional to the amount of equity that the cash pool leader owns. The larger the amount of equity, the higher is the interest rate spread (and vice versa). This is because a higher amount of equity leads to a higher credit rating for the cash pool leader. In these situations, the cash pool leader makes a profit on the interest spread and does not receive any separate/additional remuneration from the other cash pool participants. ${ }^{87}$ In all likelihood, in the in-house bank structure, the cash pool leader's credit rating will not be similar to that of a bank. Accordingly, if the cash pool leader were receiving deposits from and lending to the same entity, a spread that an independent bank could enjoy would not be available to the cash pool leader.

On the other hand, if the cash pool leader were to act as a service provider (see section 2.3.3.2., Bombardier case), it should be entitled to a service fee. ${ }^{88}$ This is because it does not bear any risks with such arrangements. In these situations, a method based upon costs (the cost-plus method or the transactional net margin method) or a limited basis point spread could be applied to determine the arm's length fee that the cash pool leader is entitled to.$^{89}$ Such could be the case in physical or notional cash pooling arrangements where the cash pool leader has a limited functional and risk profile.

\subsection{Sharing the cash pool benefit}

Cash pooling benefits (or losses) arise in light of multinational group synergies. They result from deliberate concerted action of group members. As discussed, the revised OECD Guidelines provide that benefits of such synergies should be shared among the participants in proportion to their respective contributions..$^{90}$ Thus, if the cash pool leader acts as an in-house bank, it could be argued that a major part of the cash pool benefit should be allocated to the cash pool leader. This is because the cash pool leader performs substantial functions and undertakes major risks associated with the arrangement. ${ }^{91}$ On the other hand, if the cash pool leader does not perform substantial functions or undertake substantial risks associated with the arrangement, but merely acts as a service provider (in physical or notional arrangements), the cash pool leader should not be entitled to the a major part of the cash pool benefit. In these situations, a major part of the cash pool benefit should be allocated to the cash pool participants in light of their respective contributions.

86. The cash pool leader may provide guarantees to the cash pool participants, and could also be entitled to a guarantee fees.

87. PWC, supra n. 1, at 141; Bakker, supra n. 1, at 31; Russo \& Moerer, supra n. 1 , at 44 .

88. OECD Guidelines, para. 7.14.

89. PWC, supra n. 1, at 141; Bakker, supra n. 1, at 31; Russo \& Moerer, supra n. 1 , at 44 .

90. OECD, Actions 8-10 Final Reports, supra n. 29, para. 1.162

91. This would be the case if the cash pool leader, legally and economically, bears all the risks associated with the arrangement. Russo \& Moerer, supra n. 1, at 44; PWC, supra n. 1, at 142. 
Depending on the factual circumstances, the residual profit split method ${ }^{92}$ could be applied, in principle, to split the cash pooling benefit. Imagine, in an external bank/ notional cash pooling structure, that the bank pays the entire pool benefit (interest on positive balances) to the cash pool leader. In situations where the cash pool leader acts as a service provider, the cash pool leader could retain a service fee for the activities it carries out. Thereafter, the remaining cash pool benefit could be allocated to cash pool participants on the basis of certain allocation keys that showcase their contributions (such as the size of the account balances of different entities). ${ }^{93}$

\subsection{Cash pooling documentation}

As a best practice, it is recommended that multinationals clearly document their cash pooling policy in their transfer pricing documentation. Essentially, the following information should be reflected: (i) a description of the cash pool, (ii) the terms and conditions between the cash pool leader, cash pool participants and external parties (banks), (iii) the intra-group transactions, (iv) a functional analysis of the arrangement which clearly outlines the roles and responsibilities of the cash pool members ${ }^{94}$ and $(v)$ the selection of the most appropriate transfer pricing method for the various intra-group transactions, in particular the arm's length interest rates and guarantee fees, the remuneration for the cash pool leader and the allocation of the cash pool benefit. ${ }^{95}$ This documentation serves to justify the nature of the taxpayer's dealings in the event of a transfer pricing audit (a circumstance that is currently on the rise).

\section{Impact of Other BEPS Actions on Cash Pooling}

\subsection{Domestic law changes}

Action 4 of the BEPS initiative ${ }^{96}$ deals with the perceived need to limit interest deductions. The Final Report provides recommendations for designing domestic law provisions to prevent base erosion through the use of (excess) interest expense deductions. Essentially, a fixed ratio rule is recommended to restrict interest deductions. ${ }^{97}$ In particular, the rule restricts the deduction of a group entity's interest payment to a percentage of that entity's earnings before interest, taxes, depreciation and amortization (EBITDA). The recommendation leaves open the possi- bility for countries to choose a percentage between 10\% and $30 \%$ based on certain parameters ${ }^{98}$ Furthermore, the Report recommends countries to incorporate a group ratio rule alongside the fixed ratio rule. This approach would enable entities with net interest expense above a country's fixed ratio rule to deduct interest up to the level of the net interest/EBITDA ratio of its worldwide group. The Report acknowledges that Actions 8 through 10 also affect Action $4,{ }^{99}$ and also highlights that further work will be undertaken with respect to transfer pricing aspects of financial transactions (by the end of 2017). Accordingly, Action 4 could restrict the deduction of interest paid by entities in a cash pooling arrangement, even if they are at arm's length. Consequently, cash pooling (depending on the structure) may result in effective double taxation because interest income will be taxable in the country of the depositors and the corresponding interest expense may be non-deductible in the country of the debtor. Thus, it is suggested that the $\mathrm{OECD}^{100}$ provide guidance on this topic, as it is essential. ${ }^{101}$

Action 3 of the BEPS Action Plan ${ }^{102}$ deals with controlled foreign company (CFC) rules. The Final Report provides recommendations in the form of building blocks for designing CFC rules. Essentially, building blocks are provided with respect to (i) the definition of a CFC, (ii) CFC exemption and threshold requirements, (iii) the definition of CFC income, (iv) the computation of CFC income, (v) the attribution of a CFC's income to its shareholder and (vi) rules regarding the prevention of double taxation. ${ }^{103}$ The Report provides countries the flexibility to design their CFC rules, taking into consideration their overall policy objectives. It could well be possible that income (interest or services income) ${ }^{104}$ derived by a cash pool leader's (when it operate as an in-house bank or a service entity), even though the transaction is at arm's length, could be subject to CFC rules in the parent's country. This would be the case if the cash pooling arrangement were operated from a low-tax country. ${ }^{105}$ Accordingly, taxpayers should take into consideration the applicability of the CFC rules of the parent's country vis-à-vis cash pooling arrangements.

98. Id.

99. OECD, Action 4 Final Report, supra n. 96, at 12.

100. Although the OECD has already indicated that the application of a groupwide rule should not impact the ability of a group to manage its thirdparty balances through cash pooling. OECD, Discussion Draft, BEPS Action 4: Interest Deductions and Other Financial Payments, OECD/G20 Base Erosion and Profit Shifting Project (OECD 18 Dec. 2014), para. 138.

101. Duff \& Phelps, Comments Pertaining to the Public Discussion Draft on Deductibility of Interest and Other Financial Payments, in OECD, Comments Received on Public Discussion Draft, BEPS Action 4: Interest Deductions and Other Financial Payments - Part 1 (OECD 11 Feb. 2015), at 363-372.

102. OECD, Designing Effective Controlled Foreign Company Rules - Action 3: Final Report, OECD/G20 Base Erosion and Profit Shifting Project(OECD 5 Oct. 2014), International Organizations' Documentation IBFD.

103. OECD, Action 3 Final Report, supra n. 102, at 9.

104. OECD, Action 3 Final Report, supra n. 102, at 43-55.

105. OECD, Action 3 Final Report, supra n. 102, at 14 


\subsection{Treaty law changes}

Action 6 of the BEPS Action Plan ${ }^{106}$ deals with preventing treaty abuse. The Final Report suggests that countries incorporate a minimum standard by changing the title and preamble of their treaties to reflect the objective of preventing tax evasion and tax avoidance (including treaty shopping), coupled with either (i) a principal purpose test and limitation on benefits clause, (ii) a limitation on benefits clause with a narrow principal purpose test for conduit financing situations or (iii) only a principal purpose test. ${ }^{107}$ Furthermore, the Report suggests other treaty-related changes to combat other tax avoidance structures (typically, rule shopping) ${ }^{108}$ It could well be possible that a treasury entity of a group (or cash pool leader) does not satisfy the stringent requirements under the limitation on benefits clause in order to qualify as a resident of a contracting state due to its scant economic substance ${ }^{109}$ and the fact that it derives or pays interest from/to foreign jurisdictions. Accordingly, interest paid by the net debtors in a cash pooling arrangement could be exposed to high withholding taxes in the source state if treaty benefits are denied to the cash pool leader. Thus, taxpayers should take into consideration the impact of these treaty law changes on cash pooling arrangements.

\section{The Way Forward: Dispute Resolution and Prevention}

Multinational groups consider transfer pricing issues with respect to intra-group finance as a leading area of controversy. ${ }^{110}$ The ConocoPhillips, Bombardier and Portuguese Arbitration Tax Court cases clearly show that the tax authorities have started to question the arm's length nature of cash pooling arrangements. Moreover, it has been predicted that the BEPS project will result in increased tax

106. OECD, Preventing the Granting of Treaty Benefits in Inappropriate Circumstances - Action 6: 2015 Final Report, OECD/G20 Base Erosion and Profit Shifting Project (OECD 5 Oct. 2015), International Organizations' Documentation IBFD.

107. OECD, Action 6 Final Report, supra n. 106, at 10.

108. Id.

109. Reports indicate that cash pooling arrangements are operated from Ireland with one to four employees. See J. Duffy, Ireland, in Transfer Pricing and Intra-Group Financing, supra n. 1, at 320-321.

110. T. Borstell et al., Navigating the Choppy Waters of International Tax: EY's 2013 Global Transfer Pricing Survey (2013), at 25 and transfer pricing disputes. ${ }^{111}$ Accordingly, given the fact that tax administrations could take aggressive positions regarding cash pooling arrangements, it becomes imperative for taxpayers to maintain robust documentation by carefully considering and documenting all functions performed, assets used and risks assumed, as well as the bargaining power of all related parties.

This would provide a solid foundation for avoiding common pitfalls in cash pooling arrangements, such as (i) applying debit and credit interest rates without undertaking a credit rating analysis of the cash pool leader/cash pool participant or applying such rates in light of external bank quotes, (ii) allocating the entire cash pool benefit to the cash pool leader even though it does not bear any substantial risks and (iii) maintaining long-term positions in the cash pool even though the arrangement, essentially, is to fund short-term working capital requirements. ${ }^{12}$ For arrangements that are already in cross-border litigation, taxpayers should evaluate the possibility of entering into a mutual agreement procedure under an applicable treaty that contains an equivalent to article 25 of the OECD Model $^{113}$ (or arbitration). Needless to say, if the taxpayer would like to prevent double taxation and obtain upfront certainty prior to actually implementing such arrangements, it might consider entering into a unilateral or (preferably) bilateral APA (or even - when possible - a multilateral APA) with the relevant jurisdiction(s). ${ }^{114}$

111. Chand \& Wagh, supra n. 27, at 408. See also C.H. Lowell \& M. Herrington, BEPS: Current Reality and Planning in Anticipation, 21 Intl. Transfer Pricing J. 2 (2014), Journals IBFD; M. Herrington \& C.H. Lowell, The BEPS Project: Planning in Anticipation, 21 Intl. Transfer Pricing J. 3 (2014), Journals IBFD.

112. Bakker, supra n. 1, at 32

113. Article 25 of the OECD Model provides for a dispute resolution mechanism that is also applicable for transfer pricing disputes. Currently, the MAP process, which also provides for an optional arbitration mechanism, is considered to be ineffective. The OECD, in light of Action 14 of the BEPS Action Plan, seeks to make dispute resolution mechanisms more effective. Essentially, the Final Report provides for implementation of minimum standards through a robust peer-based monitoring mechanism. In addition to committing to the minimum standard, several countries have also expressed their interest in implementing the mandatory arbitration clauses in their tax treaties. OECD, Making Dispute Resolution Mechanisms More Effective - Action 14: 2015 Final Report (OECD 5 Oct. 2015), at 9-10, International Organizations' Documentation IBFD.

114. P. Jain \& V. Chand, Location Savings: International and Indian Perspective, 43 Intertax 2 (2014), at 196-197. 